\title{
Assessing the Convergence of International Agricultural Markets as a Prerequisite for Rapeseed Sale at New Markets
}

\author{
By Alona Tanasiichuk ${ }^{1}$, Olha Hromova ${ }^{2}$, Anastasiia Abdullaieva ${ }^{3}$, Eduard Kovtun ${ }^{4}$, \\ Lina Marshuk ${ }^{5}$
}

\begin{abstract}
The article is devoted to the study of the state of the market of agro-industrial products, which is an integral part of the world market and one of the most important parts of the economic systems of most countries with market economies. It has been determined peculiarities of modern development of domestic export-oriented industries, among which are raw materials, dependence on market fluctuations on world markets. The analysis of oilseeds production volumes has been done, in particular rapeseed; the dynamics of export-import volume operations with the product group «1205 Seeds of cole or rapeseed, whether ground or not ground» has been also done. A system of indicators has been developed to assess the convergence of international agricultural markets as a prerequisite for the sale of rapeseed to new international markets. The markets of the Czech Republic and the United Arab Emirates have been identified as particularly promising markets for the sale of Ukrainian agricultural products of the commodity group «1205 Seeds of cole or rapeseed, whether ground or not ground». Assessment of the convergence indicators of the new international markets of the Czech Republic and the United Arab Emirates allowed us to conclude that these markets demonstrate convergent conditions for doing business in them by Ukrainian farmers. The most important tasks facing Ukrainian agricultural producers are substantiated: prevention of reduction of sown areas of oilseeds, production volumes of commodity group increase «12 Seeds and fruits of oilseeds», introduction to new international markets of commodity group «1205 of Ukrainian production».
\end{abstract}

Keywords: agricultural markets, markets convergence, international markets segmentation, assessment of conditions international markets convergence, international markets divergence, oilseeds, classification of goods and services, marketing attractiveness of new sales markets.

\section{Introduction}

Deepening internationalization and globalization in the international environment requires countries to increase the degree of openness of the national economy, restructure the commodity structure of exports and imports, create a strong export potential, use

| 1 Doctor of Economics Sciences, Professor of the Department of Marketing and Advertising, Vinnytsia Trade and Economics Institute, KNUTE, Ukraine.

${ }^{2}$ Ph.D. in Economics, Associate Professor of the Department Marketing and Advertising, Vinnytsia Trade and Economics Institute, KNUTE, Ukraine.

3Ph.D. in Economics, Associate Professor, Department of Finance, Vinnytsia Trade and Economics Institute, KNTEU, Ukraine.

${ }^{4}$ Ph.D., Associate Professor, Department of Management and Administration, Vinnytsia Trade and Economics Institute, KNTEU, Ukraine.

5Ph.D. in Economics, Associate Professor, Department of Finance, Vinnytsia Trade and Economics Institute, KNTEU, Ukraine. 
modern forms of economic cooperation with foreign countries, ensuring the stability of foreign economic relations. Ukraine in the global competitiveness index in 2019 ranks 85th out of 140 countries, and according to the component «Efficiency of goods and services market» ranks 57th. This means that Ukraine is well positioned in the right and appropriate combination of goods and services production, taking into consideration the specific conditions of supply and demand, as well as in ensuring that these goods can be most efficient in a market economy.

At the present stage, the market of agro-industrial products is an integral part of the world market and is one of the most important parts of the economic systems of most countries with market economies. Rapid changes in the external environment are forcing domestic companies to seek new solutions for the sale of goods on international markets.

\section{Literature Review}

Publications devoted to the development of methodological tools for marketing activities of enterprises in international markets and the study of promising areas of subject areas of international marketing development, in particular the process of forming international distribution channels, by S. Garkavenko, I. Ilyashenko, O. Kanishchenko, O. Kovinko, J. Larina, S. Madzharo, A. Mazaraki, T. Melnyk, A. Pavlenko, T. Tsygankova and others [1-10]. A significant role in their work to study the relationship between meeting the needs and requirements of all participants in business processes at the global and national levels to stimulate business has been given by scientists such as: L. Barkan, G. Vozhnyak, D. Lukyanenko, S. Pivovarova, V. Chuzhikov, who proved that the role of marketing is growing in a crisis, and the functions and tasks of international marketing are becoming more complicated [11-13]. The analysis of the published works on the topic of the research showed that they are mostly devoted to marketing management of enterprises in the market, but the issues of assessing the convergence of international agricultural markets as a prerequisite for selling domestic goods to new markets remain insufficiently studied.

\section{Results of the Study}

The agro-industrial complex is one of the Ukraine's economy priority areas. Due to the efficient functioning of agro-industrial production, the state is characterized by food security, the necessary level and quality of food supply. The aim of the study was to analyze the agro-industrial complex of Ukraine, namely the analysis of rapeseed production, its exports and imports, assessing the prospects for Ukrainian agricultural products to enter new international markets.

A feature of the modern development of domestic export-oriented industries is their raw material nature and a fairly high level of dependence on market fluctuations in world markets. The market of oilseeds is a sufficiently economically developed, formed, constantly functioning system and is important because Ukraine today is one of the leading countries in terms of exports in the world market of vegetable oils and continues to export to international markets commodities that are subject to price changes. market conditions. Today, the needs of the domestic market in oil products are fully met, as the production 
base allows to process various types of oilseeds: sunflower, rapeseed, soybeans, and the investment requires investors to pursue a prudent pricing policy for oilseeds, which encourages them to grow oilseeds and leads to strict competition in the domestic market of oilseeds

Analyzing the dynamics of the harvested area, we can conclude that the size of soybean areas in 2019 decreased by $7 \%$ compared to 2018 , there is also a tendency to decrease in the area of sunflower harvest by 3\%. And here about rapeseed, in 2019 the harvested area increased by $23 \%$ compared to 2018 (Fig. 1).

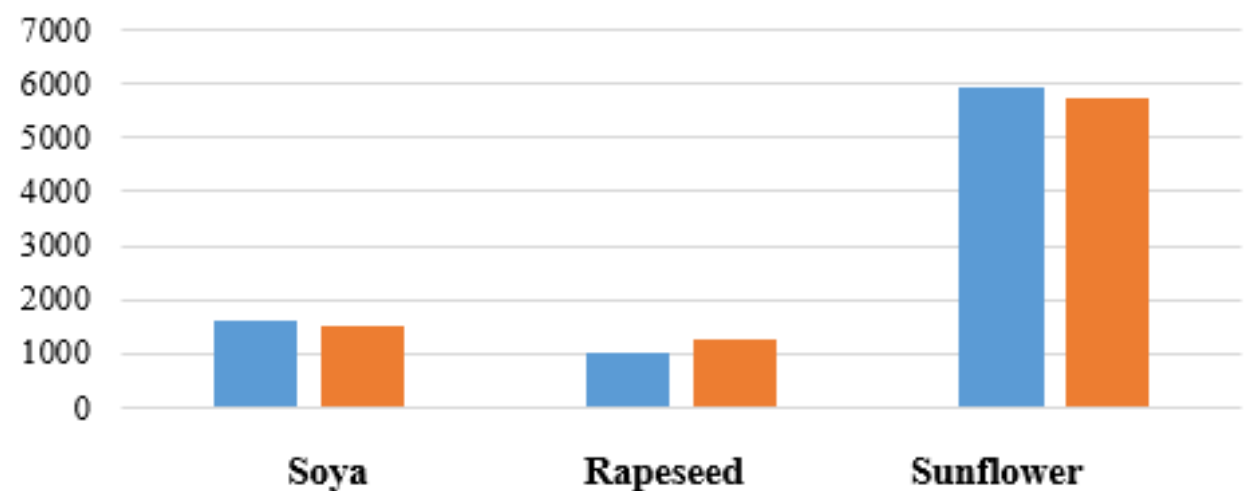

Figure 1. - Dynamics of the volume of harvested areas of the main types of oilseeds, 2018-2019, Source: developed by the author based on [14]

Regarding the dynamics of oilseeds production, we see that soybean production in 2019 is $18 \%$ lower than in 2018, and sunflower production in 2019 increased by $7 \%$ in 2019 , while rapeseed production increased by $8.4 \%$ for the compared period (Fig. 2).

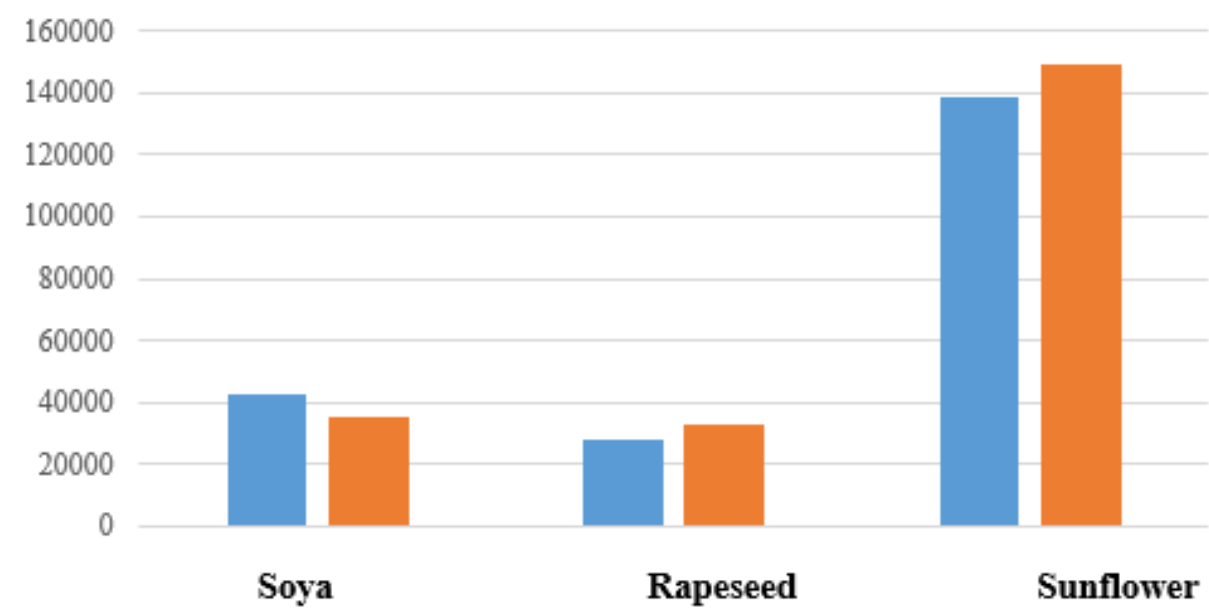

Figure 2. Dynamics of production volumes of the main types of oilseeds, 2018-2019, thousand tons Source: developed by the author based on [14] 
According to the classifier of foreign economic activity, rapeseed is included in the 12 group «Seeds and fruits of oilseeds; other seeds, fruits and grains; technical or medicinal plants; straw and fodder "and in subheading 1205», 1205 Seeds of cole or rapeseed, whether ground or not ground» (chart 1).

Chart 1. Dynamics of the main indicators of the commodity group production «1205 Seeds of cole or rapeseed, whether ground or not ground» in Ukraine.

\begin{tabular}{|c|c|c|c|c|c|}
\hline \multirow[b]{2}{*}{ Indicators } & \multicolumn{3}{|c|}{ Years } & \multirow{2}{*}{\begin{tabular}{|c|} 
Relative \\
Deviation \\
$2017 / 2018$ \\
\end{tabular}} & \multirow{2}{*}{\begin{tabular}{|c} 
Relative \\
Deviation \\
2018/2019
\end{tabular}} \\
\hline & 2017 & 2018 & 2019 & & \\
\hline $\begin{array}{l}\text { The area from which the crop was harvested, } \\
\text { thousand hectares }\end{array}$ & 788,5 & 1031,3 & 1276,8 & 130,8 & 123,8 \\
\hline Crop capacity, $\%$ & 27,9 & 26,5 & 25,7 & 95,0 & 97,0 \\
\hline Collection volume, thousand centners & 21974,9 & 27802,4 & 33029,2 & 126,5 & 118,8 \\
\hline Sales volume, thousand centners & 1922,7 & 2382,7 & 2792,1 & 123,9 & 117,2 \\
\hline
\end{tabular}

Source: developed by the author based on [9]

Currently, both in the domestic and world markets, there is a high demand for oilseeds and oil and fat products, as the global trend is a balanced diet and consumption of organic products, which stimulates the growth of production. Organic products as a product of market novelty need increased attention to its promotion in the domestic market and the formation of commitment and loyalty of consumers in international markets. A fullfledged domestic market for organic products with a complete production cycle is formed rather slowly. Given the development trends of the domestic market of organic products and the possibility of selling oilseeds to international markets, an important new direction for Ukrainian agricultural holdings will be the rapeseed cultivation .

Commodity group «1205 Seeds of cole or rapeseed, whether ground or not ground» is one of the main crops, the value of which lies in the great variety of its useful properties and a wide range of applications. The processing of rapeseed produces oil, which can be used for consumption in kind or as a raw material for the processing industry. Technical rapeseed oil is used in the production of biodiesel. A by-product of processing is rapeseed meal (cake), which contains valuable fodder properties.

The carried out analysis of sown areas of the commodity group «1205 Seeds of cole or rapeseed, whether ground or not ground» by farms of all categories in 2019 by region allowed us to conclude that the rapeseed market in Ukraine is developing rapidly as the area under sowing increases, so compared 2019 to 2018, the territory increased by $32 \%$, and due to it the volume of harvest increases. So, in 2019 it is 19\% more than in 2018, and there is a positive trend (Fig. 2). 


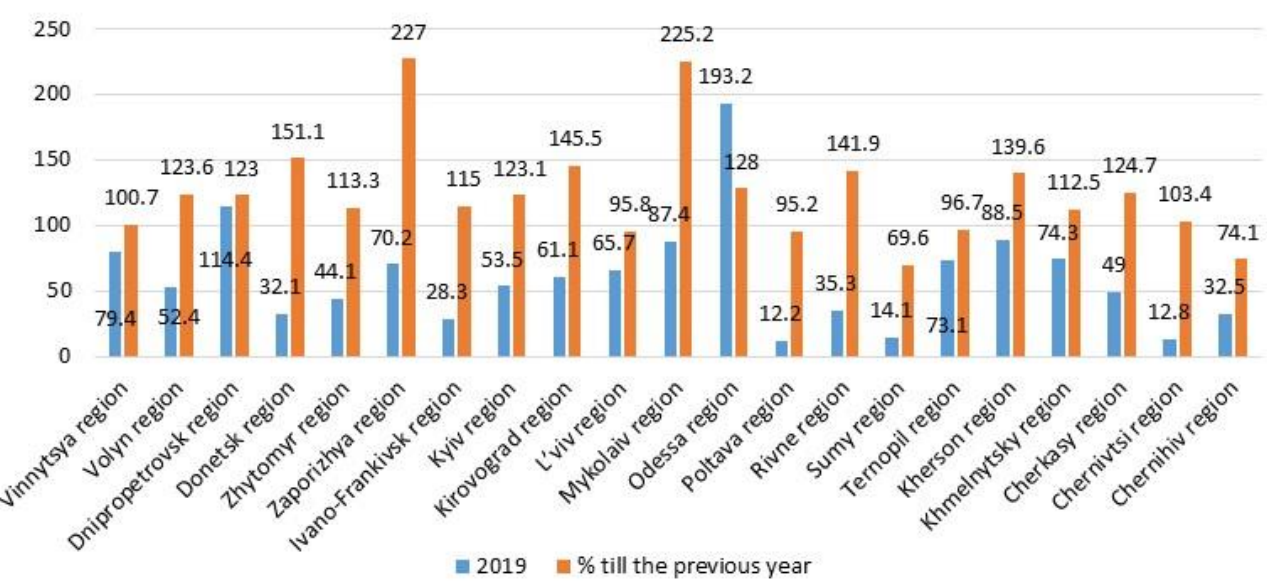

Figure 2. The volume of sown areas of the commodity group «1205 Seeds of cole or rapeseed, whether ground or not ground》 farms of all categories in 2019 by region

Source: developed by the author based on [9]

From Figure 2 it can be concluded that the increase in sown areas of the product group «1205 Seeds of cole or rapeseed, whether ground or not ground» occurred in Zaporozhye, Donetsk, Kirovograd and Kherson regions by $127 \%, 51 \%, 45 \%$ and $39.6 \%$, respectively. Also, the largest sown area in Ukraine is in Odessa region, which is 193.2 thousand hectares, then Dnepropetrovsk 114.4 thousand hectares, and 79 thousand hectares in Vinnytsia region.

According to the site «Trade map», Ukraine ranks 2nd in the export of the product group «1205 Seeds of cole or rapeseed, whether ground or not ground», and covers $10 \%$ of world exports, which in value terms is 1010936 thousand dollars. In terms of world leadership, Canada ranks 1st with an export share of $42 \%$ and a value of 4450825 thousand dollars, 3rd place in the ranking of rapeseed exporting countries takes Australia, which has $9 \%$ of world exports and a value of 959362 thousand dollars [16].

The international activity of agricultural enterprises of Ukraine in 2019 is impressive, because the export of Ukrainian rapeseed comes to 28 markets. The largest share of Ukraine's exports is to the German market - 31\%, which in value terms is 308,830 thousand dollars, the second place is occupied by the Belgian market $(29 \%)-291439$ thousand dollars, the third place belongs to the French market, which exports $13 \%$ of Ukrainian rapeseed. The next step is Poland (5\%) - 48863 thousand dollars, and the fifth place is occupied by the partner-importer - the market of Pakistan, which exports rapeseed for 32687 thousand dollars.

Having analyzed the volume of imports of the product group «1205 Seeds of cole or rapeseed, whether ground or not ground» in 2019, the main leaders-importers in the world market, concluded that in the studied markets there is demand for agricultural products, in particular for the product group «1205 Seeds of cole or rapeseed, whether ground or not ground» (Fig. 3). 


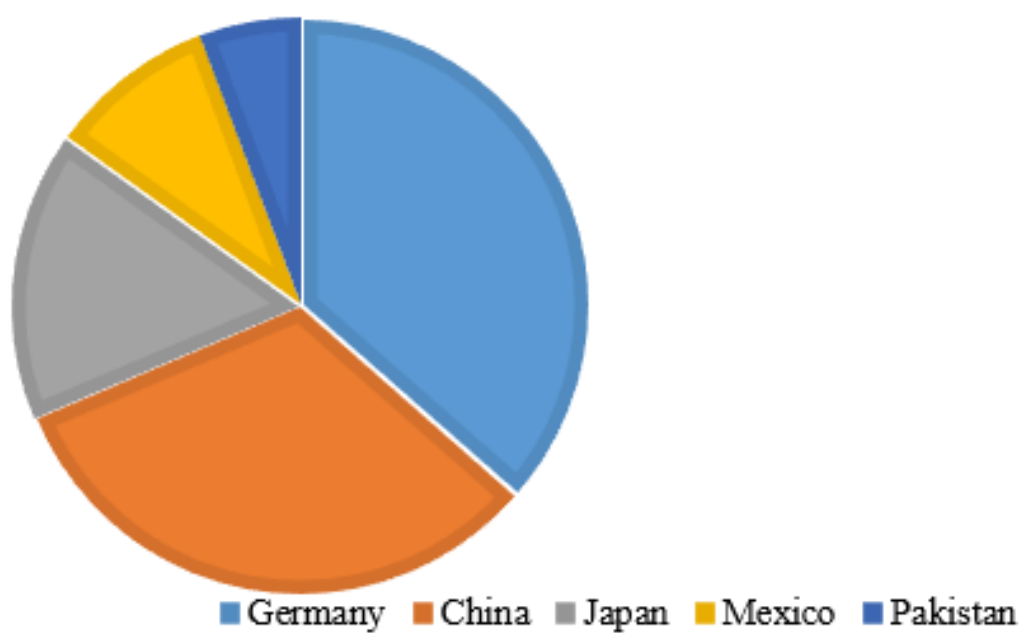

Figure 3: Volumes of imports of the commodity group"1205 Seeds of cole or rapeseed, whether ground or not ground " to the world's leading importing markets, 2019, thousand dollars,\%

Source: developed by the author based on [10]

Since in Ukraine there is a tendency to increase production of the product group «1205 Seeds of cole or rapeseed, whether ground or not ground», it is necessary to look for new international markets and links for export activities, as production significantly exceeds the level of self-sufficiency of the product group «1205 Seeds of cole or rapeseed, whether or not crushed» in Ukraine, which remains stable at 1.92 [15].

Segmentation of foreign markets is carried out according to the criterion «Share in world imports of the product group «1205 Seeds of cole or rapeseed, whether ground or not ground».

Segment A includes markets, the share of product group «1205 Seeds of cole or rapeseed, whether ground or not ground» in world imports is from 1 to $25 \%$, markets of segment B - the share of product group «1205 Seeds of cole or rapeseed, crushed or uncrushed» in the world imports is from 0 to $1 \%$, and the markets of segment B - the share of the product group «1205 Seeds of cole or rapeseed, whether ground or not ground» in world imports is $0 \%$.

So, in 2018, segment A includes the markets of 15 countries, 10 of which Ukraine exports the product group "1205 seeds of cole or rapeseed, crushed or uncrushed": the markets of Germany, Belgium, Mexico, France, Pakistan, Poland, USA, Austria and the Netherlands. Other markets in 5 countries should be considered as potentially new international markets for the sale of Ukrainian rapeseed, including the markets of China, Japan, the United Arab Emirates, the Czech Republic and Canada. Segment B has markets in 23 countries: Iran, Latvia, Spain and others. Other markets in 62 countries belong to segment B.

In our opinion, the promising markets for export activities of Ukrainian enterprises are the countries of group A, namely those 5 countries in which there is a demand for the product group "1205 Seeds of cole or rapeseed whether ground or not ground ". 
Chart 2. Marketing attractiveness indicators of new international markets for Ukraine by product group "1205 Seeds of cole or rapeseed, crushed or uncrushed", 2018

\begin{tabular}{|l|c|c|c|c|c|c|}
\hline Countries & $\begin{array}{c}\text { Share in } \\
\text { World } \\
\text { imports, } \%\end{array}$ & $\begin{array}{c}\text { Trade } \\
\text { Balance } \\
\text { in } 2018\end{array}$ & $\begin{array}{c}\text { Annual increase } \\
\text { in import value, } \\
2017-2018\end{array}$ & $\begin{array}{c}\text { Concentration } \\
\text { of supplier } \\
\text { countries }\end{array}$ & $\begin{array}{c}\text { Ease } \\
\text { of doing } \\
\text { business }\end{array}$ & $\begin{array}{c}\text { Average } \\
\text { distance } \\
\text { between } \\
\text { countries }\end{array}$ \\
\hline Arab Emirates & 3,3 & -360341 & -10 & 0,48 & 11 & 5022 \\
\hline Canada & 1,2 & 4320806 & 36 & 0,71 & 22 & 7615 \\
\hline China & 20,3 & -2225621 & 3 & 0,9 & 46 & 6457 \\
\hline Czech Republic & 1,3 & -2233 & 24 & 0,12 & 35 & 688 \\
\hline Japan & 10 & -1109008 & -2 & 0,84 & 39 & 8208 \\
\hline
\end{tabular}

Source: developed by the author based on $[10,16]$

The trade balance of the studied markets is negative, except for the Canadian market, which means that countries spend more on imports of goods than they receive from exports of their goods, ie the ratio of export coverage to imports is lower 1.

The annual increase in import value by the studied product group reflects the growth of turnover, ie there is a trend of growth of imports of the product group «1205 Seeds of cole or rapeseed», whether ground or not ground in Canada, China and the Czech Republic by 36, 3, 24 percent, respectively. Decrease in import turnover by 10 and 2 percent in the United Arab Emirates and Japan, respectively.

High intensity of competition (the coefficient is approaching one) in the markets of China (0.90), Japan (0.84) and Canada (71). The average intensity of competition is present in the United Arab Emirates with a rate of 0.48 . In the Czech market, the intensity of competition fades, as the value of the coefficient is close to zero, and is 0.12 out of 1 .

The Ease of Doing Business indicator is determined by the World Bank on the basis of annual data between countries. Higher scores indicate better conditions for doing business, easier business regulation, and existing protection of property rights. Based on the results of the study, we can conclude that the regulation and implementation of business is available in the markets of China, Japan and the Czech Republic. More complex business process in the markets of the United Arab Emirates and Canada. The study of selected markets allowed to consider in more detail the opportunities and prospects for domestic producers of the product group «1205 Seeds of cole or rapeseed, whether ground or not ground» to increase the share of these products in world exports.

Opportunities for international cooperation development can be determined by the foreign trade quota, which characterizes the intensity of international trade relations, calculated as the ratio of foreign trade to GDP, as a percentage.

If the open trade index is less than $30 \%$, it is considered that the market is an economy with a low level of openness, and the greater the value of the foreign trade quota, the more open the national economy. Consider the dynamics of the index of trade openness in potential international markets (Fig. 4). 


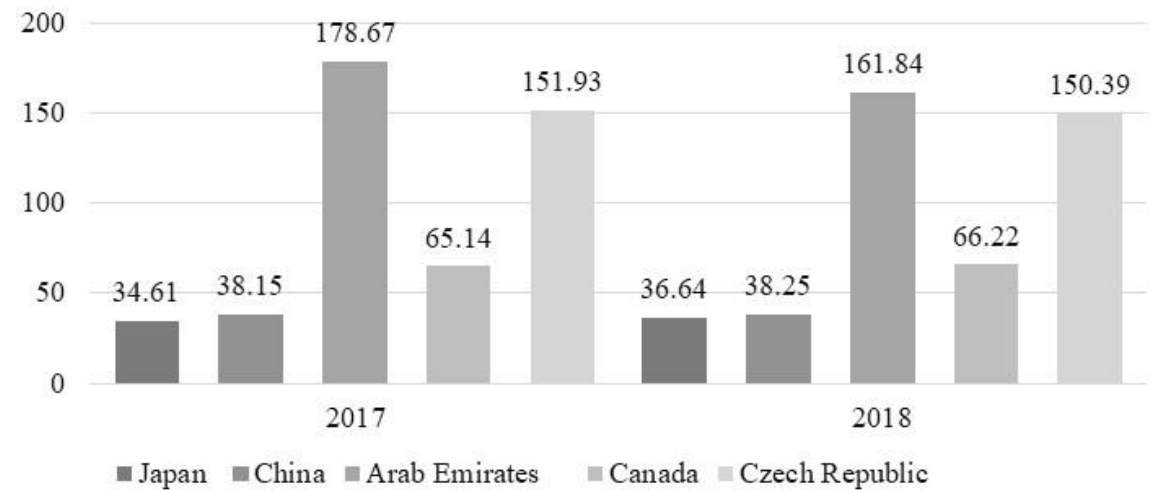

Figure 4. Dynamics of the open trade index, 2017 - 2018, \%

Source: developed by the author based on $[11,16]$

Economies with an average level of openness in the markets of Japan and China, which in 2018 amounted to $36.64 \%$ and $38.25 \%$, respectively. Canada's market openness index is about $66 \%$. While the high level of openness of the economy in the market of the United Arab Emirates (over 160\%) and also in the Czech Republic (150\%).

The macroeconomic environment of the country's market plays an important role in assessing the position of the international market in the world economy, because the market achieves high competitiveness in those sectors of the economy in which it has significant competitive advantages. A strong economy must have stable markets and be governed by the law. A comprehensive analysis of market competitiveness is covered by the Global Competitiveness Index (GCI), which annually publishes ratings for each group of factors influencing competitiveness, which is based on 113 indicators taken into consideration which 12 control indicators were formed $[11,17,18]$.

Chart 3 - Potential markets estimation for the sale of the product group «1205 Seeds of cole or rapeseed, whether ground or not ground» of Ukrainian production according to the criteria of the GCI rating 2018-2019.

\begin{tabular}{|l|c|c|c|c|c|c|c|c|c|c|}
\hline \multirow{2}{*}{ Criteria } & \multicolumn{2}{|c|}{ Japan } & \multicolumn{2}{c|}{ China } & \multicolumn{2}{c|}{ Canada } & $\begin{array}{c}\text { Arab } \\
\text { Emirates }\end{array}$ & $\begin{array}{c}\text { Czech } \\
\text { Republic }\end{array}$ \\
\cline { 2 - 16 } & 2018 & 2019 & 2018 & 2019 & 2018 & 2019 & 2018 & 2019 & 2018 & 2019 \\
\hline Institutions & 20 & 19 & 65 & 58 & 11 & 13 & 19 & 15 & 43 & 44 \\
\hline Infrastructure & 5 & 5 & 29 & 36 & 25 & 26 & 15 & 12 & 18 & 20 \\
\hline Macroeconomic stability & 41 & 42 & 39 & 39 & 1 & 1 & 1 & 1 & 1 & 1 \\
\hline Healthcare and primary education & 1 & 1 & 44 & 40 & 12 & 14 & 79 & 92 & 41 & 48 \\
\hline Higher education and vocational training & 26 & 28 & 63 & 64 & 11 & 12 & 53 & 39 & 25 & 29 \\
\hline Efficiency of the market of goods and services & 5 & 6 & 55 & 54 & 20 & 24 & 11 & 4 & 47 & 55 \\
\hline Labor market efficiency & 18 & 16 & 69 & 72 & 6 & 8 & 42 & 34 & 47 & 48 \\
\hline Financial market development & 10 & 12 & 30 & 29 & 11 & 9 & 31 & 31 & 40 & 47 \\
\hline Technological readiness & 3 & 5 & 26 & 18 & 34 & 35 & 6 & 2 & 42 & 42 \\
\hline Market size & 4 & 4 & 1 & 1 & 15 & 16 & 28 & 32 & 42 & 42 \\
\hline Level of business development & 14 & 17 & 43 & 36 & 13 & 12 & 33 & 31 & 25 & 32 \\
\hline Innovations & 8 & 7 & 24 & 24 & 13 & 16 & 35 & 33 & 29 & 29 \\
\hline Global Competitiveness Index & 5 & 6 & 28 & 28 & 12 & 14 & 27 & 25 & 29 & 32 \\
\hline
\end{tabular}

Source: developed by the author based on $[11,17,18]$ 
According to this study, the markets of Japan, Canada and the Czech Republic have deteriorated their positions in the ranking, the Chinese market remains in 28th place out of 141, the market of the United Arab Emirates is rapidly developing its position and ranks 25 th.

The biggest loss on the component of the «Institution» - minus 2 points in the Canadian market, and minus 1 position in the Czech market. There is a positive trend of increasing position in the markets of Japan, China and the United Arab Emirates by 1, 7, 4 positions, respectively. According to the criterion of «Macroeconomic Stability», no changes took place in all markets except Japan, which lost 1 position. Regarding the criterion «Higher education and vocational training», there was a positive trend of positions in the market of the United Arab Emirates only by 14 positions. The growth of competitiveness took place in the criterion «Efficiency of the market of goods and services» on the 7 th and 1st position in the market of the United Arab Emirates and China, respectively, lost positions in Japan (-1), Canada (-4), Czech Republic (-8). There was a change in the criterion of «Labor market efficiency» as follows: in the market of Japan (+2), the United Arab Emirates (+8), China (-3), Canada (-2), the Czech Republic (-1). Regarding the criterion «Financial market development», the improvement of positions is observed only in the markets of China and Canada. According to the criterion of «Technological readiness», the improvement took place in the markets of China, the United Arab Emirates - by +8 and +4 , respectively. The size of the market in almost all studied markets remains unchanged. The level of business development increased by 1 position in the markets of China $(+8)$, Canada and the United Arab Emirates. Regarding the criterion of «Innovation», the markets of the United Arab Emirates and Japan improved their positions - by 2 and 1 position, respectively.

Thus, as a result of the potential sales markets assessment of the product group «1205 Seeds of cole or rapeseed, whether ground or not ground» of Ukrainian production according to the criteria of the GCI rating, conclusions were made on the competitiveness of selected countries. Analyzing the mentioned above, we concluded that for all world markets 2019 was unstable, which significantly affected their micro- and macroeconomic environment, but each country has a developed market and industry structure, as well as there is a high activity of economic entities, scientific potential and qualified specialists. Comparing the selected indicators of the studied markets, we can conclude that all five markets are promising for the product group «1205 Seeds of cole or rapeseed, whether ground or not ground» Ukrainian production, which is competitive in the world market. In order to complete the process of selecting new international markets for the sale of the Ukrainian-made product group «1205 Seeds of cole or rapeseed, whether ground or not ground», it is necessary to assess their convergence as a prerequisite for the sale of this product group.

Assessing the criterion «Average distance between countries» for the studied markets, it was determined that close to the distance to Ukraine are the markets of segment A «distance up to 5 thousand $\mathrm{km}$ » and segment $\mathrm{B}$ - «from 5 thousand to 7 thousand $\mathrm{km}$ », and markets segment $\mathrm{B}-\ll 7$ thousand $\mathrm{km}$ and more» is considered divergent for the domestic product group «1205 Seeds of cole or rapeseed, whether ground or not ground». Let's evaluate the convergence indicators of markets that are close in distance to the 
Ukrainian market - segments A and B (Chart 4).

Chart 4 - Convergence indicators estimation of new international markets for sale on them of the commodity group "1205 Seeds of cole or rapeseed, whether ground or not ground " of Ukrainian production, 2018-2019.

\begin{tabular}{|l|c|c|c|c|c|c|}
\hline \multirow{2}{*}{ Markets / Indices } & \multicolumn{3}{|c|}{ Arab Emirates } & \multicolumn{2}{c|}{ Czech Republic } & \multicolumn{2}{c|}{ China } \\
\cline { 2 - 8 } & 2018 & 2019 & 2018 & 2019 & 2018 & 2019 \\
\hline Business Freedom Index (Max =100) & 80 & 80 & 73 & 72 & 55 & 56 \\
\hline Freedom of trade index (Max =100) & 84 & 84 & 87 & 86 & 73 & 73 \\
\hline Economic freedom, general index (Max =100) & 78 & 78 & 74 & 74 & 58 & 58 \\
\hline
\end{tabular}

Source: developed by the author based on $[11,17,18]$

One of the indicators of convergence of new international markets for the sale of the commodity group «1205 Seeds of cole or rapeseed, whether ground or not ground» of Ukrainian production was chosen «Index of Political Stability», which is set in the range from minus 2.5 points (weak) to plus 2, 5 points (strong), and shows the likelihood that the government will be destabilized or overthrown by unconstitutional or violent means, including politically motivated violence and terrorism. Thus, the best result is the «Index of Political Stability» in the markets of the Czech Republic (+1.04) and the United Arab Emirates (+0.74). The weakest in the Chinese market $(-0.26)$, which allows us to conclude that there are divergent conditions for doing business in this market.

The «Index of Economic Freedom» indicator shows the level of liberalization of interaction between the state and business. The Business Freedom Index is based on the following indicators: launch of business procedures, licenses and business closure. The largest index is shown by the markets of the United Arab Emirates and the Czech Republic, which have 80 and 72 points out of 100, respectively. The low indicator of economic freedom is demonstrated by the Chinese market, which in 2019 amounted to 56 points, which allows us to conclude that there are divergent conditions for doing business in this market.

The Freedom of Trade Index indicator is based on two indicators: the weighted average tariff rate and non-tariff barriers (including quantity, price, regulatory, customs and investment restrictions, and direct government intervention). The Czech market has the highest number of points (86), the market of the United Arab Emirates - (84), and the Chinese market 73 points.

Assessing the convergence indicators of the new international markets of the Czech Republic, the United Arab Emirates, China for sale on them of the product group «1205 Seeds of cole or rapeseed, whether ground or not ground» Ukrainian production allows us to conclude that the markets of the Czech Republic and the United Arab Emirates show convergent business conditions. - activities of Ukrainian farmers. The Chinese market demonstrates the existing divergent conditions for doing business by Ukrainian farmers. We believe that since there is an approximation of legislation in the agro-industrial complex to EU legislation in Ukraine, as well as deregulation in the agro-industrial complex, there is state support and preferential taxation in agriculture. So, in general there is a development of agricultural policy in science, education and innovation. on creating the preconditions for Ukrainian farmers to enter new markets of the European Union and 
the existing convergence of the Ukrainian market and the markets of the EU countries. Thus, the Ukrainian agro-industrial enterprises can consider the Czech market as particularly promising for the product group «1205 Seeds of cole or rapeseed, whether ground or not ground» Ukrainian production.

The market of the United Arab Emirates should also be considered as a new market for the commodity group «1205 Seeds of cole or rapeseed, whether ground or not ground» of Ukrainian production, as it has convergent conditions for the sale of agricultural products.

And the Chinese market can be considered as new for the product group «1205 Seeds of cole or rapeseed, whether ground or not ground» Ukrainian production, subject to certain changes in their political and economic spheres, as the assessment identified some divergent conditions for doing business.

\section{Conclusion}

In the context of the global crisis of 2020, which was caused by a mass epidemic, the world's financial markets experienced the largest decline since the global financial crisis. This phenomenon significantly slows down the development of the economy of all countries, affects world stock markets and leads to the closure of a number of enterprises, rising unemployment, outflow of investment, the presence of protests in society and more. There was a very serious impact on the economic activity of individual markets. Experts emphasize that the world economy may recover within a year after the end of the pandemic. At present, after significant losses, the world economy must recover, and markets must renew their trade and economic ties, so Ukrainian agricultural producers face crucial tasks: preventing reductions in sown areas, increasing oil production, bringing new products to new international markets. «1205 Seeds of cole or rapeseed, whether ground or not ground» made in Ukraine. Domestic companies should consider the markets of the Czech Republic and the United Arab Emirates as particularly promising for the sale of the commodity group. «1205 Seeds of cole or rapeseed, whether ground or not ground» Ukrainian production.

\section{References}

Harkavenko S. S. (2002), Marketing. K.: Libra, 712 p. (Ukraine).

Illyashenko S. M., Illyashenko N.S. (2016), Prospects and threats of the fourth industrial revolution and their consideration while choosing innovative growth strategies. No 1. pp. 11-21. (Ukraine).

Kanishhenko O. L. (2005), Formation of market relations in Ukraine. No 12 (55). pp. 40-44. (Ukraine).

Larina Ya., Hrinevich L. (2014), Modern theoretical foundations of international trade of biomass and its implications in Ukraine. Scientific Journal «Problems of world agriculture». No 4. pp. 47-57.

Larina Ya. (2017), Innovation and marketing strategies of enterprises on the innovative food products market. Annals of Marketing Management \& Economics. Part.3, No 1, pp.33-47.

Larina Ya.S., Zaval'nyuk K.S. (2017), Quantitative indicators of the dynamics of agricultural formations development as indicators of economic growth of the agricultural sector. Part 38. pp. 20-31. (Ukraine).

Madzharo S. (1977), International Marketing. M.: International relations, 790 p. (Russia).

Mazaraki A. A., Melnyk T. M., Yuxymenko V. V., Kostyuchenko V. M., Kudyrko L. P. (2015), World market of goods and services. K. : KNUTE, 720 p. (Ukraine). 
Kotler F., Keller K., Pavlenko A. (2008), Marketing management. K.: Ximdzhest, 720 p. (Ukraine). [10] Cyhankova T. M. (2004), International marketing: theoretical models and business technologies: Monograph. Kyiv: KNEU,. 137 p. (Ukraine).

Kovin'ko O. M. (2016), International markets for agricultural products. Foreign trade: economics, finance, law. No 2. pp. 65-76. (Ukraine).

Kovin'ko O. M. (2016), Practical aspects of agricultural enterprises business activity under the conditions of international diversification: international markets assessment attractiveness. Strategy of economic development of Ukraine. No 39. pp. 99-107. (Ukraine).

Pivovarova S. Je., Barkana L.S. (2000), International Management. Piter: Spb.: «Piter», 680 p. (Russia).

Luk'janenko D.G., Chuzhikov V., Vozhnjak G. (2010), Convergence of Poland and Ukraine economic models. Monograph. Kyiv: KNEU, 719 p. (Ukraine).

Luk'yanenko D.H., Chuzhykov V., Vozhnyak Mixal H. (2013), Convergence and divergence in Europe: Polish and Ukrainian cases: Monograph. Kyiv: KNEU, 688 p.

Official website of the State Statistics Service of Ukraine, 1998-2016. URL: http://www.ukrstat.gov.ua/ [Last accesed 20.08.2020].

Trade statistics for international business development. URL: http://www.trademap.org. [Last accesed 08.08.2020].

Global economy. URL: https://www.theglobaleconomy.com/Ukraine/gdp current local currency/[Last accesed 10.08.2020].

The Global Competitiveness Index. URL: https://www.weforum.org/reports/the-global-competitvenessreport-2018 [Last accesed 15.08.2020].

Ministry of Agrarian Policy and Food. URL: http://minagro.gov.ua/.LLast accesed 22.08.2020]. 